Article

\title{
River Activism, "Levees-Only" and the Great Mississippi Flood of 1927
}

\author{
Ned Randolph \\ Department of Communication, University of California San Diego, La Jolla, CA 92093, USA; E-Mail: egrandol@ucsd.edu
}

Submitted: 26 September 2017 | Accepted: 15 November | Published: 9 February 2018

\begin{abstract}
This article investigates media coverage of 19th and early 20th century river activism and its effect on federal policy to control the Mississippi River. The U.S. Army Corps of Engineers' "levees-only" policy-which joined disparate navigation and flood control interests-is largely blamed for the Great Flood of 1927, called the largest peacetime disaster in American history. River activists organized annual conventions, and later, professional lobbies organized media campaigns up and down the Mississippi River to sway public opinion and pressure Congress to fund flood control and river navigation projects. Annual river conventions drew thousands of delegates such as plantation owners, shippers, bankers, chambers of commerce, governors, congressmen, mayors and cabinet members with interests on the Mississippi River. Public pressure on Congress successfully captured millions of federal dollars to protect property, drain swamps for development, subsidize local levee districts and influence river policy.
\end{abstract}

\section{Keywords}

activism; commerce; democracy; floods; levees; media; media history; Mississippi River; river conventions

\section{Issue}

This article is part of the issue "Media History and Democracy", edited by David W. Park (Lake Forest College, USA).

(C) 2018 by the author; licensee Cogitatio (Lisbon, Portugal). This article is licensed under a Creative Commons Attribution 4.0 International License (CC BY).

\section{Introduction}

River conventions and river activism in the 19th and early 20th centuries shaped federal responsibility over U.S. waterways, unifying geographical and political groups around a common policy of flood and navigational improvements on the Mississippi River. Through written "memorials" sent to Congress and published in newspapers to drum up public pressure, conventions repeatedly tied the Mississippi River to national identity, framing the river as a unifying force in a divided nation, particularly after the Civil War.

The question of how to manage navigation and prevent catastrophic floods along the Mighty Mississippi provided a common exercise for Americans of different geographic areas and political stripes. This shared problem among Southern and Midwestern states also created opportunities for the emerging West to flex its growing political might by leveraging congressional votes for Mississippi improvements in exchange for interventions to Western waterways.

This article focuses on discourses that emerged from conventions and considers the press's role in producing public sentiment. The rise of river conventions coincided not only with an improvement in transportation that allowed delegates to travel longer distances for meetings, but also the rise of the advertising-driven "penny press"-whose business model eschewed partisanship for increased circulation (Schudson, 2003). Penny papers were at the leading edge of journalistic innovation before the Civil War. Horace Greeley, for instance, not only published the influential penny paper, New York Herald Tribune, but he also helped organize the largest river convention ever in 1847 in Chicago. Publicity for the Chicago convention in Greeley's and other Whig papers attracted 10,000 delegates to a "mud-flat" city of only 16,000 people (Williams, 1949, p. 607).

This article also posits that the press is both an effect and a producer of public consciousness. It enables cultural citizenship through the ritual of common readership. Newspapers organized what Benedict Anderson called "imagined communities" by creating the ceremony of common readership. Each reader knows that "the ceremony he performs is being replicated simultaneously by thousands (or millions) of others of whose existence he is confident, yet of whose identity he has not 
the slightest notion" (1983, p. 35). While river conventions gained popularity through engagement with a common object of the Mississippi River, they spoke to a reading public that was organized around event-driven news. Convention delegates staged their events for news coverage, which often focused on the size and atmosphere of crowds in attendance. Delegates explicitly performed emissary-like roles on behalf of a presupposed public at home. They promoted conventions through newspaper announcements and generated news reports from the convention floor. Memorials of resolutions that emerged at a convention's conclusion were printed in newspapers and sent to Congress. They often invoked the iconic imagery of the Mississippi River such as the "Father of Waters", "the Nation's Canal", and "A Ribbon of Commerce and Empire".

These 19th gatherings would seem to be on their face the archetypal public sphere that Jürgen Habermas (1974, p. 50) idealized: one that mediated between society and the state through a salon of private citizens to air public opinion. This public opinion emerges "when a reasoning public is presupposed". Specifically, it is an opinion directed at power. It can happen formally through voting or informally through a kind of demonstration. Explicating Habermas, Nancy Fraser (1990) identifies this public as one of "discursive relations" and a theater for debating and deliberating rather than for buying and selling. These self-appointed members must represent their interests as being aligned with that of a presumed public by using newspapers as their instrument.

Convention delegates performed before multiple audiences: those in attendance, as well as an audience mediated through newspapers, which included the congressional representatives they hoped to impress upon. I argue that the audience of delegates-which Michael Warner (2002) calls a public witnessing itself in visible space with a "sense of totality bounded by the event or shared physical space" - was a critical ingredient of staging news events that allowed delegates to speak to a presupposed reading public. This latter public "comes into being only in relation to texts and their circulation" (2002, p. $50)$. It is through this mediated public that discourses circulate. Imagining this reading public was a critical function of not only the delegate performances but also of congressional representatives who received reports about the conventions. These articles produced an image of the Mississippi River that exceeded even its vast material body. Discourses positioned the river as an organizing force of a political economy of culture and trade as it flowed through a divided nation, connecting free and slave states. The river was not only an object of intervention, but a political canvas over a diverse and contentious nation.

Methodologically, I've relied on news accounts from the period, convention proceedings, congressional records, memorials, publications by river lobbies and secondary scholarly sources. This article comes out of my ongoing dissertation research on the cultural history of the Mississippi River Delta and Louisiana coast.

\section{Gibbons, Federal Jurisdiction and Political Organizing}

Congress's official oversight of the Mississippi River followed the 1824 U.S. Supreme Court decision, Gibbons v. Ogden (1824), which upheld that the "Commerce Clause" of the U.S. Constitution gave the federal government the power to regulate river navigation. The Gibbons case, which was regularly cited as constitutional justification for federal intervention into the economy, allowed Congress to direct the Army Corps of Engineers to make navigational improvements to river channels. Early surveys of the Mississippi River revealed that the Ohio River at Louisville was crossed by 21 sandbars that "render it impassable by steamboats six months in a year". Reports confirmed that the Lower Mississippi held thousands of submerged trees or "snags" that were fatally hazardous to riverboats, while the river itself, because of its alluvial nature, constantly tried to change course (Lippincott, 1914, p. 636).

The General Survey Act, passed in 1826, provided $\$ 75,000$ in appropriations for "internal improvements" in what was the first Rivers and Harbors legislation to improve navigation (Pabis, 1998). Yet flood control was officially relegated to local interests. Relying on private landowners generally led to uneven construction standards. A weak levee upriver might collapse and spread misery to all. Major storms also brought fears of saboteurs who would intentionally severe a levee across the river to release pressure on their own defenses. Without official federal oversight on flood control, any significant levee aid required political pressure on congressional representatives.

A number of destructive floods between the years 1828 and 1849 in the lower portion of the Mississippi River stoked early political stirrings for federal river and levee improvements. Advocates argued through the press that only a central government could provide enough resources for complex surveys and levee projects that individual states could not muster. Local resources were further hampered by the Panic of 1837, which coincided with multiple presidential vetoes of River and Harbor bills, as well as the Mexican War, the Seminole uprising in Florida and the advent of the railroads (Cotterill, 1919):

Hardly a day passed that did not see the assembling of a mass meeting at some point in the quest to urge on their representatives and prepare memorials. The improvement of the Western waters, the building of hospitals and armories, the construction of levees and military roads, all these the general government was called upon to do by a people whom the panic of 1837 had left entirely without resources of their own. (Cotterill, 1919, p. 18)

Even Southern states-righters, who otherwise fought expansion of federal power, acknowledged that only fed- 
eral engineers had the expertise and resources necessary to survey the Mississippi River.

An 1844 flood broke the levee at Bonnet Carré, 30 miles upriver from New Orleans, and sent the river into Lake Pontchartrain for six months, disrupting traffic. By early 1845, calls for a Southern and Western Convention came from many sources. The "river problem" provided commercial organizations and local governments in the Middle West and the South a common interest to ward off challenges from emergent railroads and the Erie Canal, both of which were publicly subsidized and capturing trade. The Port of New York prior to the Erie Canal's completion counted $\$ 33$ million in imports and $\$ 31$ in exports. By 1845 , exports grew to $\$ 45$ million, and to $\$ 75$ million two years later. The increasing rivalry of the Great Lakes turned into a contest between North and South, both of which were attempting to secure an economic and political allegiance with the West (Cotterill, 1919).

The resulting Mississippi River Improvement Convention in Memphis that opened July 4, 1845 marked the first ever multi-state convention for river work. A Southern Democrat, named John C. Calhoun, was elected chairman. He called the Mississippi the "great inland sea of the country" that the government was obligated to protect and improve just as it did the Atlantic Seaboard. The memorial sent to Congress and published in newspapers called for the improvement of the Ohio and Mississippi Rivers and their tributaries, the deepening of the mouth of the Mississippi, and the connection of the river and the Great Lakes by ship canal. "Similar resolutions were adopted at other conventions, except that assemblies north of St. Louis were often called more specifically to (remove) rapids of the Mississippi" (Lippincott, 1914, pp. 644-645).

The Richmond Times published a letter by Calhoun that the river was "the common highway" among states and should be regulated by the Commerce Clause (Calhoun, 1846a). A similar report ran in The Mississippian that the "conclusion is irresistible that its commerce comes as fully within the power to regulate commerce as that of the coast itself" (Calhoun, 1846b). But Calhoun's preference for boosting Southern infrastructure alienated many legislators from the North and Middle West, who felt that the Upper Mississippi interests were neglected (Williams, 1949). This came to a head in August 1846, when President James Polk vetoed the Rivers and Harbors Bill, condemning the "disreputable scramble" for aid (O'Neill, 2006, p. 47). After the veto, William Hall, a "disaffected" Democrat and member of the Lake Steamboat Association, reached out to his contacts in Chicago, Detroit, Cleveland, Buffalo, Syracuse, Rochester, Utica, Albany, Hartford, New Haven, Springfield, Boston and Providence (Williams, 1949). They hastily gathered at the Rathburn Hotel in New York to plan a second convention (American Whig Review, 1847). Organizers held pre-convention press briefings in several cities. They placed news stories featuring the coming convention and printed the lists of delegates. Whig papers such as Greeley's New York Herald claimed the convention was non-partisan. The American Whig Review stated that the convention was "so thoroughly Whiggish in its aims, although studiously and designedly divested of any mere party organization" (American Whig Review, 1847, p. 112).

Greeley in regular dispatches argued the convention would permanently guarantee the welfare of the North and West (Lippincott, 1914). The convention was preceded by a grand procession "staged with floats, bands, military units, and the inevitable gorgeously caparisoned volunteer fire companies" (Williams, 1949, pp. 608-614). The American Whig Review swooned:

nothing could be better arranged, or better adapted to the ends in view, than the preparations and accommodation for the Convention, both while assembled as a body, and when scattered amongst the various public and private houses in the town. (1847, p. 112)

The paper praised the decisive unanimity of the convention "that not a case occurred, during the whole deliberations, where a sort to division by states was necessary-all questions having been carried by acclamation that amounted almost to absolute unanimity" (American Whig Review, 1847, pp. 112-113). In the convention's memorial to Congress, delegates repeatedly cited the Commerce Clause and its interpretation by multiple administrations from Jefferson to Polk to argue for river improvements (Semi-Weekly Union, 1847).

\section{Flood Control and Swamp Busters}

Private landowners, planters and municipal authorities couched their arguments for flood control through economic imperatives. As American settlers in the 1830s and 1840 s began clearing the alluvial lands in Arkansas and Mississippi, it became increasingly clear that reliance on private landowners to provide levees was insufficient (Saikku, 2012). Yet Congress was still unwilling to dispense direct appropriations for levee building. Political pressure mounted from the South as flooding threatened newly claimed agricultural lands and growing townships. An 1849 flood deluged New Orleans when it broke through the levee at Pierre Sauvée's plantation 17 miles upriver. Within three days the water reached the French Quarter. Nervous uptown residents considered severing the levee at the New Basin Canal behind the French Quarter, soliciting the threat of armed response by downtown residents (Rogers, 2008). Three weeks later, the upper New Basin Canal collapsed, which deluged 220 midcity blocks and forced the evacuation of 12,000 residents (Colten, 2009).

After the 1849 flood, Congress acceded to pressure from Southern constituents to pass the Swampland or "Swamp-buster" Acts, which provided a mechanism for levee construction through land reclamation. Millions of acres of federal riverine bottomlands on the Mississippi 
were turned over to states, which sold them to pay for levee building and flood control. As states from other parts of the country demanded similar grants, Congress extended the program in 1850 to California, Florida, Oregon, and eleven states in the Ohio-Mississippi Valley. Historian John Barry argues that Eastern politicians agreed to pass the swampland grants to keep the South from forging a political alliance with the West (Barry, 1997). By 1909, nearly 82 million acres had passed into private hands through the swampland program, some for as little as ten cents to $\$ 1.25$ per acre (Wright, 1907).

The swampland program also boosted the flood control cause by sponsoring Army Corps of Engineers surveys, which consistently recommended that the federal government build protective levee projects (Barry, 1997). The program led to the formation of state levee districts which directed construction work and provided flood control advocates with a political base for lobbying efforts (O'Neill, 2006).

\section{Civil War Disruptions}

But the issue of slavery would shatter national political parties into sectional interests. By the 1860 s, Democrats had split into Northern and Southern organizations. Regions competed for new settlement and private investment. Newspaper editors in Mississippi, for instance, recruited planters from states bordering the Mason-Dixon line, where abolitionist sentiments were growing (Harrison, 1951). A settlement boom in the Delta was comparable to a second gold rush. Cheap farmland attracted thousands of white slaveowners from the Atlantic seaboard to make their fortune. Slaves were brought in forced migration over land and sea from the older slave states to the newer cotton states. By 1850, a quarter of New Orleans' population had come from the North (Dattel, 2006).

An article reprinted in the New Orleans-based De Bow's Commercial Review in 1858 touted the strength of local levees to protect newly reclaimed delta farmland:

We can levee successfully!...We have but one outlet, the Yazoo Pass, and the levee there, the heaviest and highest in the world, has stood the flood. It stood because it was properly and securely built. (Harrison, 1951, p. 13)

The population in Mississippi and Alabama doubled between 1840 and 1860 from 179,074 whites and 195,211 slaves in 1840 to 354,000 whites and 436,631 slaves in 1860 . Cotton production more than doubled in half the time, from 194 million pounds in 1849 to 535.1 million pounds in 1859 (Dattel, 2006).

\section{Post-War Unification}

After the wholesale destruction from the Civil War, calls for river improvements focused on repairing the wartorn infrastructure and, ostensibly, the national psyche.
During the 1867 St. Louis River Improvement Convention, the chairman, Gen. William Vandever of lowa, noted sacrifices of "immense treasures of blood and money" and said the Mississippi had the power to unite "heart and hand now in burying the animosities of the past" by improving common prosperity (St. Louis Proceedings, 1867). A New York Times article described an 1869 river convention in New Orleans in which the Chamber of Commerce convention hall was decorated with such mottos as: "The South extends to the Northwest a cordial welcome"; "The West and the South join hands"; "The river to the sea and the sea to the river" (1869).

From 1866 to 1882 , Congress passed a Rivers and Harbors bill each year which pleased local merchants, many of whom turned to river shipping to avoid the cost of railroad monopoly rates. A New York Times reporter in 1878 wrote from a convention in New Orleans that, "Railroads might come and go but this Mississippi River would flow on to the end of the time" (New York Times, 1878). Conventions called in St. Louis, Chicago and Quincy issued extensive arguments about freight cost savings from river shipments and the potential of new inland markets. They argued that domestic commerce was far more important to the U.S. economy than international commerce and, therefore, deserved the same congressional support as lighthouses and harbor construction. At an 1877 convention in St. Paul, one of the speakers argued that it took less time to sail across the Atlantic from Europe than to traverse 800 miles from St. Paul to St. Louis because of rocks and low water. The memorial to Congress stated, "No valid objection to improvement of our seaports, but the rivers of the Mississippi Valley are entitled to equal commercial facilities" (Waterhouse, 1877).

In the Lower Mississippi Valley, Southern activists argued that the difficulties of maintaining levees and shipping channels on the river had to be solved in tandem because they were caused by the same thing: a river that carried large volumes of silt and rapidly shifted its banks (O'Neill, 2006). Floods also crossed state borders and disrupted the political economy of the nation. Southern interests argued then (as they do now) that they carried the burden of the nation's floodwaters. States along the lower portion of the river couldn't maintain bridges and levees used by trains for interstate commerce. It was, therefore, clearly a duty of the central government to facilitate commerce (St. Louis Proceedings, 1867). Arkansas delegates said the lack of levees left the National Road from Memphis to Little Rock frequently under water and impassable (Cotterill, 1919).

\section{Public Relations}

Appeals for intervention were explicitly aimed to apply pressure through the press. An 1877 call by businessmen from 18 states to convene a Mississippi River Improvement Convention in St. Paul specifically focused on public relations: "to organize the public sentiment of the Mississippi Valley in support of a systematic pressure upon 
Congress to recognize the importance of navigation from St. Paul to St. Louis, which was impassible during low water stages" (Waterhouse, 1877). The St. Louis GlobeDemocrat published a call by the St. Louis Chamber of Commerce for a convention of "representative men of the Mississippi Valley, including editors of newspapers, to meet in that city, Oct. 11, for the consideration of the river improvement question" (St. Louis-Globe-Democrat, 1877). Separately, the Daily Arkansas Gazette out of Little Rock reprinted a column from the Memphis Appeal, entitled "Facts and Figures are an Unanswerable Argument in Favor of the Improvement of the Mississippi" (Young, 1877). The column was written by Rep. Casey Young, a Democrat from Tennessee, to the president of the Memphis Chamber of Commerce requesting an appointment of delegates to the St. Paul convention.

At the 1881 Mississippi River Improvement Convention meeting in St. Louis, the president of the Merchants Exchange called for the general desire "communicated through the press, emanating from various commercial bodies recognizing the importance of united and intelligent action on a subject of the most vital importance" (Official report of the proceedings of the Mississippi River Improvement Convention, 1881, p. 5). News stories of the day may have elevated self-appointed insiders as representatives of "the public", but printed accounts also reflected the complexity of satisfying the different needs of states affected by the river:

If all the members of the eighteen great states directly interested in this grand work would pull together, they could pass a bill that would provide for the immediate commencement of the work on the Mississippi on a scale commensurate with the importance of the undertaking. (St. Louis Globe-Democrat, 1881)

The undertaking was vast indeed and was rationalized through not only commercial appeals, but also the cultural importance of the river as an object of unification. The New York Times gave a hero's welcome to Jefferson Davis, the defeated president of the Confederacy, who walked into the 1878 river convention hall to a standing ovation in New Orleans. In his speech, he claimed solidarity with not only the state of Mississippi but "every state bordering upon that great river" (New York Times, 1878).

The Washington Post reported from a river convention in 1884 where the Mississippi was called the "Father of Waters" by the convention secretary GL Wright, who said:

In no manner had the provident care of the creator for the ideal Republic been so manifested as in the location of the Mississippi River. The great empire in the West now demanded the full improvements of that great river so that it would not only float the commerce of the country, but would remain a bond of good will and fellowship between the sections. (Washington Post, 1884)
Clearly cultural appeals were common currency in tying the river to federal oversight. One question that continues to vex historians is what effect these discourses had on the Army Corps of Engineers' "levees-only" policy that increased the danger of flooding to the constituents it attempted to appease.

\section{The Birth of "Levees-Only"}

The disastrous 1949 floods that inundated most of the Lower Mississippi Valley and resulted in the 1849-1850 Swampland Acts also increased congressional focus onto the river itself. Floods were not the only river problem. "At the mouth of the Mississippi enormous sandbars often blocked access to the Gulf of Mexico. Sometimes 50 ships waited there for the sandbars to dissipate enough to allow passage into or out of the river; the largest ships sometimes waited as long as three months" (Barry, 1997, p. 34). There was still no consensus on how to best to control floods and improve navigation. On September 30, 1850 , Congress authorized a complete survey of lower valley from Cairo, Illinois to the Gulf. "The aim was to discover the laws governing the Mississippi River and determine how to tame it" (Barry, 1997, p. 35).

Two competing reports were assigned, one to the civilian engineering faction and one to the Army Corps of Engineers. The corps report, which would take 11 years, had a lasting impact on national river management policy. Its author, Andrew Atkinson Humphreys of the U.S. Topographical Corps, suffered multiple health problems during the survey work, but finished his Report upon the Physics and Hydraulics of the Mississippi River just months before the Civil War. Humphreys concluded that building continuous levee lines would "concentrate" the flow of the river (Pabis, 1998). Assisted by Lt. Henry L. Abbot, a fellow West Point alumnus, Humphreys' survey teams painstakingly obtained data on riverine channel cross sections and topographical and geological formations. They took measurements from the confluence of the Mississippi and Ohio rivers to the mouth of the Mississippi at the Gulf of Mexico. They studied the tributaries of the Lower Mississippi. They applied insights from geology and European hydraulics to challenge the conventional wisdom about alluvial deposits.

The result, declared the American Journal of Science, was "one of the most profoundly scientific publications ever published by the U.S. government" (Shallat, 1990, p. 41). Their final analysis recommended closing the remaining natural outlets to maintain all water flow within the main river channel. This endorsement of a "singlechannel theory" tied flood control interests to navigation interests, which was politically attractive (Pabis, 1998).

But the survey was fundamentally flawed. It assumed the riverbed consisted of hard blue clay, based on discoveries of clay deposits at the head of Bayou Plaquemine, in Bayou Lafourche and on the prairies in between. Blue clay was found in an artesian well in New Orleans and in the Yazoo Swamps in Mississippi. "Although not 
one of these facts may be considered itself conclusive, it must be allowed that together they afford good grounds for doubting the recent alluvial character of the bed of the Mississippi, even as far down as the head of passes", Humphreys concluded erroneously (Pabis, 1998, p. 440). He argued that since the bed of the Mississippi River was made of clay, it could not be sufficiently "scoured" through flow restriction (Reuss, 1985).

The Corps of Engineers accepted these conclusions for decades. Though it was challenged by other civil engineers and powerful individuals, it provided political cover for Southern flood control interests. When an 1874 flood upriver from New Orleans broke the levees and deluged swaths as wide as 50 miles in some places, Congress turned to Humphreys loyalists. An appointed commission was headed by Gen. G. K. Warren, who had served under Humphreys. Henry Abbot, who coauthored the Humphreys report, sat on the commission board (Reuss, 1985). The Warren Commission conducted no fieldwork and looked only at Humphreys' report. It subsequently endorsed "levees-only" policy and blamed uncoordinated levee building by local levee districts for producing a defective system. It proposed creating regional districts with federal aid to build a system of levees, which Humphreys and Abbot had recommended in 1861. On the basis of the Warren Commission's report, in 1875 Representative Randall L. Gibson of Louisiana created a House Committee on Mississippi River Levees, which "became a battering ram for flood control interests for 35 years" (U.S. Army Corps of Engineers).

By the 1880s, army engineers were building flood control levees all along the Lower Mississippi River. As the levee lines became more complete, downstream residents continued to suffer. The "levees-only" approach was causing the river to carry a greater volume of water thus forcing engineers to construct taller levees. A break in the larger, modern levees wreaked tremendous devastation. Yet other proposals to manage river flooding, such as opening spillway outlets into bayous, required the government to appropriate private lands, which was met with resistance. "Levees-only" represented a political compromise. It was supported by enough engineers and scientists, along with Delta landowners.

By the turn of the century, Southern and Western activists seeking federal flood control aid for the Mississippi and Sacramento rivers were working alongside activists seeking federal flood control aid for all navigable rivers. They broadened their public appeals and traded votes in Congress, which often passed veto-proof legislation with something for each region, giving birth to the phrase "pork-barrel" construction (O'Neill, 2006). In this sense, activists began to professionalize.

\section{Professional Lobbies}

In the 1880s, the Reform Movement began emphasizing rational informed citizenry and professionalism. Reformists favored pamphlets over parades and urged vot- ers to make a rational choice among candidates and policies over emotional allegiance (Schudson, 2006). Newspapers began to open bureaus in the nation's capital at the same time as lobbyists and press agents proliferated. "One journalism critic noted that by 1920 there were nearly a thousand 'bureaus of propaganda' in Washington, D.C." (Schudson, 2003, p. 83). New lobby groups used the rhetoric of efficiency and progress favored by the Progressive Movement. The first permanent river lobby was formed in 1890 by planters and levee district boards from Louisiana and Mississippi, called the Interstate Mississippi River Improvement and Levee Association. Like the Corps of Engineers, the association opposed outlets and promoted levees, citing statistics. They established a bureau of correspondence in Washington, D.C., sent speakers to other river organizations and circulated thousands of documents.

The group's strategy was to arm delegations with "facts and figures to demonstrate the right of the people of the Mississippi Valley" and create "continual agitation" to strengthen public sentiment in favor of larger appropriations by the central government (Thompkins, 1901 , p. 4,). A column by the group's president, Mississippi planter Charles Scott, addressed to "America's Businessmen", touted millions of acres of potential farmland that awaited cultivation in the Delta. "The total value of the staple crops raised on these lands heretofore brought under the plow, will approximate seventy-five millions of dollars per annum!! What a wonderful empire of richness lies here yet undeveloped". The group published columns in the Southern Manufacturers Record by Louisiana Supreme Court Judge N. C. Blanchard who rationalized constitutional authority for congressional intervention, as well as articles by former Mississippi Attorney General, State Senator T. C. Catchings, and Corps of Engineers officers James A. Quinn, Smith S. Leach, and T. G. Dabney among others (Thompkins, 1901).

In 1901, a separate group of New Orleans shippers and bankers formed the National Rivers and Harbors Congress in protest of the filibuster of a Rivers and Harbors bill. Adopting the slogan, "a policy, not a project", they were the first group to consult directly with congressional committees. They held each annual meeting in Washington, D. C., where they relocated their headquarters in 1911. The group lobbied initially for flood control on the Lower Mississippi River, but eventually promoted nationwide flood control. Sen. Joseph E. Ransdell of Louisiana chaired its executive committee and traveled with other legislators in 1906 to meet with waterway associations around the country. They attracted members from shipping companies, regional trade and river organizations, chambers of commerce, farming organizations, and levee districts from other river valleys. Their 1906 convention drew 189 commercial associations and 14 governors. The 1908 convention drew 287 mayors (O'Neill, 2006). Ransdell, on his way to view the Panama Canal with a contingent of Congressmen, was quoted in the New York Tribune as saying the country is 
waking up to the importance of a settled water policy: "We believe that the people of the country are coming to feel that in view of the terrible congestion of traffic on the rail ways, the demonstrated cheapness of transportation by water...and efficiency of water competition (to be) the best regulator of railway rates" (New York Tribune, 1907). In their 1911 convention in New Orleans, Ransdell said they had increased $\$ 20$ million in expenditures to $\$ 30$ million in the six years since the group was formed, and turned semi-annual bills into annual appropriations (New York Times, 1911).

By 1917, Ransdell and the National Rivers and Harbors Congress came under intense criticism for their lobbying methods. A New York Tribune article cites multiple examples of targeted campaigns by the NRHC against critics. Sen. Jones from Washington State accused the group of trying to "enlist the newspapers of Washington State to make a campaign against him". Sen. Kenyon of lowa said that one of his Davenport constituents had received a letter from Sen. Ransdell regarding Mr. Kenyon's opposition to a bill. In response Sen. Ransdell said he had merely advised the Davenport correspondent to "to do all that he could with his friends to support the bill" (New York Tribune, 1917).

\section{Multipurpose Approach}

Despite the Corps' resistance, many engineers began to advocate various combinations of outlets and spillways at the turn of the century to address flooding. Capt. John Millis of the Fourth Mississippi River Commission District recommended construction of two artificial outlets in the levees to disperse floodwaters (Reuss, 1985). At a 1911 National Rivers and Harbors Convention, Corps' Chief Engineer W. H. Bixby said individual Corps engineers recognized the need for multipurpose developments, including power, irrigation, drainage, and bank and levee protection. The New York Board of Trade and Transportation in 1913 published a report from its members supporting multipurpose development. The president of the Mississippi River Commission, Army engineer C. M. Townsend, went on record supporting multipurpose development. The National Drainage Congress created in Chicago in 1911 called for the conservation of water and land and tied drainage improvements to public health. Some convention speakers argued that the General Welfare Clause of the Constitution justified drainage in part because of the connection of malaria to swamps (O'Neill, 2006). Yet the corps argued that such projects could harm navigation.

Meanwhile, a devastating flood in 1912 broke water records at 17 of the 18 river gauges south of Cairo, III., even though its volume was far less than the volume of the 1882 flood. This indicated that the riverbed of the levee-constrained river was rising. That same year, a convention of planters and levee district officials in Memphis formed the Tri-State Levee Association (later renamed the Mississippi River Levee Association), which used the devastation of the 1912 flood to argue for stronger levees. The group included business owners, lawyers and planters from Chicago to New Orleans. They lobbied for aid to the Lower Mississippi River and eventually allied with the National Rivers and Harbors Congress to support flood control aid for the Mississippi and Sacramento rivers. The group's secretary-manager, John A. Fox, wrote letters, pamphlets, and several books, and he organized a speaker's bureau (O'Neill, 2006). A book printed by the group, A National Duty, featured endorsements by the Democratic, Republican and Progressive parties. It featured a prominent article by the Mississippi River Commission, entitled "The Bed of the River is Not Rising" (Fox, 1914). It also included sympathetic photos of flood victims, tenants and black farm laborers stranded in the 1912 deluge (Fox, 1914).

The public relations campaign that coincided with the 1912 flood and another devastating flood the next year garnered enough public sentiment to sway all three major political parties to incorporate planks in their platforms "recognizing the national character" of the disasters and committing their candidates "to the speedy solution of the problem". The presidential nominees all specifically subscribed to declarations (Floods and Levees of the Mississippi River Supplemental Report, 1914). President Taft declared that the 1912 flood demonstrated that flooding on the Lower Mississippi River is a national problem. His 1912 reform party platform stated that the federal government should assume a "fair portion" of the burden in building levees, which also included opening Western and Southern waterways to federal protection (O'Neill, 2006, p. 118). An expanded federal presence was endorsed by the Louisiana Bankers Association, the National Drainage Congress, the New Orleans Progressive Union, and the National Flood Prevention and River Regulation Conference in New Orleans, as well as newspapers across the country (Proceedings and Debates of the Congress, 1912). A renewed alliance was forged between the West and South.

After years organizational work, personal politicking by activists, actions by sympathetic legislators, flood control supporters eventually won official aid for the Mississippi and Sacramento rivers with the 1917 RansdellHumphreys Flood Control Act (Pearcy, 2000). It directed the Corps of Engineers to provide levee aid for the Mississippi and Sacramento rivers. The federal government would pay up to two-thirds of levee construction. Local interests remained responsible for acquiring the rightsof-way and some maintenance costs.

Yet, in the spring of 1922, the lower Mississippi River flooded again. The river was so high that its tributary waters flooded six Yazoo-Mississippi Delta counties. Some critics blamed the flood on the closure of the Cypress Creek Gap by the Corps of Engineers the year before. The only remaining outlet on the Mississippi was at Old River, which was created by Captain Shreve in 1831 to shortcut the Mississippi to the Red River. The cut would later threaten to open a permanent course for the Missis- 
sippi down the Atchafalaya River away from New Orleans, which is a story for another article.

\section{Conclusion}

During the winter and spring months of 1927, the Mississippi River well surpassed record flood stages. Prolonged rainfall in the headwaters swelled its tributaries and increased the already elevated water levels in the Lower Mississippi. In April 1927, waters began to rise precipitously, approaching 60 feet above mean sea-level. Federal levees along the Lower Mississippi began to breach. By May, floods had devastated 32 towns and cities and pushed the Ohio tributary backwards (Saikku, 2012). On May 24, the river broke through Old River and sent 30-foot waters down the Atchafalaya. The breach panicked New Orleans authorities, who convinced the Corps of Engineers and Mississippi River Commission to dynamite the levee south of the city. They used 39 tons of dynamite over 10 days, sacrificing rural farmers and fur trappers downstream to save the city. When it was over, 20 percent of the river's volume poured through a 3,200 feet wide breach into St. Bernard and Plaquemines Parishes (Barry, 1997).

Referred to as the greatest peacetime disaster in U.S. history by Secretary of Commerce Herbert Hoover, the 1927 floods caused staggering economic losses and human suffering. Over 16 million acres in seven states were inundated and property loss estimates varied from $\$ 236$ to $\$ 363$ million. Nearly 700 people are known to have died. Another 637,000 were left homeless. The American Red Cross, responsible for most of the relief work, provided food and shelter for more than 300,000 people in refugee camps. As suggested by Charlie Patton's "High Water Everywhere", black refugees were particularly harmed. Imprisoned in refugee camps, they were coerced to perform manual labor and prevented from fleeing the Delta because planters were afraid of losing their workforce (Saikku, 2012). In the aftermath of the devastation, Congress ordered the Army Corps of Engineers to examine the flood problem in a national context. As a result, the Corps Chief Lt. General Edgar Jadwin proposed a nearly $\$ 300$ million program of multipurpose development for the Mississippi and its tributaries, named Project Flood (Reuss, 1982).

It would be inaccurate to attribute the failed "leveesonly" policy to any one group, agency or even government. It was a manifestation of political agendas that evolved over a century. This article focuses primarily on the role of river conventions in fomenting public discourse through the press and memorials to Congress to justify federal intervention in the Mississippi River, which flowed through a diverse and contested nation. An oft overlooked form of democratic practice, river conventions organized political action that preceded the professionalized state and special interest groups we associate with contemporary democratic practices. To respond to the Mississippi River in those early American decades was to respond to changing physical and political variables. Moving through states and jurisdictions, the river forged alliances with divergent and convergent interests that swirled together for a common application or outcome, much like a whirlpool or eddy that kicks out and then re-emerges into the main current.

The Mississippi River helped suture the public body consciousness by giving conventions and newspapers a common frame of focus. It functioned discursively as an object of unification, and materially as a potentially catastrophic force. The politics of river improvement and the growing weight of the conventions and press were entangled components of emerging forms of democracy that saw a public growing in power and advocating for a larger role of its national government.

\section{Conflict of Interests}

The author declares no conflict of interests.

\section{References}

American Whig Review. (1847, August). The Chicago Convention. American Whig Review, 6(2), 111-122. Retrieved from http://ebooks.library.cornell.edu/ cgi/t/text/text-idx?c=amwh;idno=amwh0006-2

Anderson, B. (1983). Imagined communities: Reflections on the origin and spread of nationalism. London: Verso Books.

Barry, J. (1997). Rising tide: The Great Mississippi River Flood of 1927 and how it changed America. New York, NY: Simon \& Schuster.

Calhoun, J. C. (1846a, June 26). Mr. Calhoun's report. The Richmond Times.

Calhoun, J. C. (1846b, August 5). Mr. Calhoun made the following report. The Mississippian, p. 2.

Colten, C. (2009). Perilous place, powerful storms: Hurricane protection in coastal Louisiana. Jackson, MS: University Press of Mississippi.

Cotterill, R. (1919). Improvement of transportation in the Mississippi Valley 1845-1850. Madison, WI: The University of Wisconsin Library.

Dattel, E. R. (2006, October). Cotton in a global economy: Mississippi (1800-1860). Mississippi History Now. Re trieved from http://mshistorynow.mdah.state.ms.us/ articles/161/cotton-in-a-global-economy-mississippi $-1800-1860$

Floods and Levees of the Mississippi River Supplemental Report, 53 Cong. section, report 300, part 2 (1914, February 24) (report submitted by Mr. Humphrey's of Mississippi).

Fox, J. (1914). A national duty: Mississippi River flood problem: How the floods can be prevented. Washington, DC: J. W. Bryan Press. Retrieved from https:// archive.org/details/cu31924022876233

Fraser, N. (1990). Rethinking the public sphere: A contribution to the critique of actually existing democracy. Social Text, 25/26, 56-80. 
Gibbons v. Ogden, 22 U.S. 1 (1824).

Habermas, J. (1974). The public sphere: An encyclopedia article (F. Lennox \& S. Lennox, Trans.). New German Critique, 3(Autumn, 1974), 49-55.

Harrison, R. (1951). Levee districts and levee building in Mississippi: A study of state and local efforts to control Mississippi River floods. Stoneville, MS: Delta Council.

Lippincott, I. (1914). A history of river improvement. Journal of Political Economy, 22(7), 630-660.

New York Times. (1869, May 24). Opening of the Louisiana Commercial Convention: Opening of the Louisiana mottoes in the hall of assembly: Preliminary Business. New York Times.

New York Times. (1878, December 6). Jefferson Davis talks: Urging the needs of the Mississippi. New York Times.

New York Times. (1911, July 26). Seek aid for waterways: National Rivers and Harbors Congress Meets Dec. 6, 7, and 8. New York Times, p. 12.

New York Tribune. (1907, March 7). Better waterways: Congressman Ransdell says they will regulate railway evils. New York Tribune, p. 14.

New York Tribune. (1917, July 26). Senators assail rivers Congress for lobbying: National body accused of fighting congressman who opposes it. New York Tribune.

O'Neill, K. (2006). Rivers by design. Durham, NC: Duke University Press.

Official report of the proceedings of the Mississippi River Improvement Convention (1881, October) (Report prepared by the Committee of twenty-one).

Pabis, G. (1998). Delaying the deluge: The engineering debate over flood control on the Lower Mississippi river, 1846-1861. The Journal of Southern History, 64(3), 421-454.

Pearcy, M. (2000). A history of the Ransdell-Humphreys Flood Control Act of 1917. Louisiana History: The Journal of the Louisiana Historical Association, 41(2), 113-159.

Proceedings and Debates of the Congress, Volume 48, Part 12 (1912).

Reuss, M. (1982). The Army Corps of Engineers and floodcontrol politics on the Lower Mississippi. Louisiana History: The Journal of the Louisiana Historical Association, 23(2), 131-148.

Reuss, M. (1985). Andrew A. Humphreys and the development of hydraulic engineering: Politics and technology in the Army Corps of Engineers, 1850-1950. Technology and Culture, 26(1), 1-33.

Rogers, J. D. (2008, May 1). Development of the New Or- leans flood protection systems prior to Hurricane Katrina. Journal of Geotechnical and Geoenvironmental Engineering, 134(5), 602-617.

Saikku, M. (2005). Taming the rivers. In M. Saikku (Ed.), Thomas Pynchon and the dark passages of history (pp. 138-164). London and Athens, GA: University of Georgia Press.

St. Louis Proceedings. (1867). Proceedings of the River Improvement Convention, Feb. 12-13. St. Louis, MO: Order of the Union Merchants' Exchange of St. Louis.

St. Louis Globe-Democrat. (1877, September 22). Reporting a call by the St. Louis Chamber of Commerce. St. Louis Globe-Democrat.

St. Louis Globe-Democrat. (1881, January 23). Washington letter. St. Louis Globe-Democrat.

Schudson, M. (2003). Where news came from: The history of journalism. The sociology of news. New York, NY: W. W. Norton \& Company, Inc.

Schudson, M. (2006). The varieties of civic experience. Citizenship Studies, 10(5), 591-606. doi:10.1080/ 13621020600955033

Semi-Weekly Union. (1847, July 16). The Chicago convention. 1847. Semi-Weekly Union.

Shallot, T. (1990). Building waterways, 1802-1861: Science and the United States Army in early public works. Technology and Culture, 31(1), 18-50.

Thompkins, F. H. (1901). Riparian lands of the Mississippi River-past-present-prospective. Retrieved from https://archive.org/details/riparianlandsmi00tompg oog

Warner, M. (2002). Publics and counterpublics. Public Culture, 14(1), 49-90.

Washington Post. (1884, February 6). Our greatest river: A convention of 500 delegates seeking its improvement. Washington Post, P4.

Waterhouse, S. (1877). A memorial to Congress to secure an adequate appropriation for a prompt and thorough improvement of the Mississippi River. St. Paul, MN: Mississippi River Improvement Convention.

Williams, M. (1949). The Chicago River and Harbor Convention, 1847. The Mississippi Valley Historical Review, 35(4), 607-626.

Wright, J. O. (1907). Swamp and overflowed lands in the United States. Ownership and reclamation. Washington, DC: United States Department of Agriculture.

Young, C. (1877, October 7). The Great River: Facts and figures that are an unanswerable argument in favor of the improvement of the Mississippi. Daily Arkansas Gazette.

\section{About the Author}

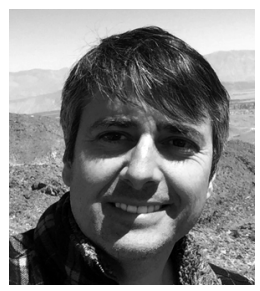

Ned Randolph is a PhD candidate in Communication from the University of California San Diego and former speechwriter for the mayor of New Orleans and journalist. His dissertation research investigates the cultural history of the Lower Mississippi River Delta and Louisiana wetlands. 